Talía. Revista de estudios teatrales

ISSN-e 2659-806X

\title{
Pasen y lean: los orígenes del teatro infantil español en la Biblioteca Pedro Cerrillo de la Universidad de Castilla-La Mancha
}

\author{
César Sánchez Ortiz*; Ernesto Rodríguez Abad**
}

Recibido: 4 de febrero de 2020 / Aceptado: 30 de junio de 2020

Resumen. Este texto pretende, como principal objetivo, dar a conocer el fondo antiguo de teatro infantil de la Biblioteca Pedro Cerrillo de la Universidad de Castilla-La Mancha, además de reivindicar los estudios e investigaciones en un género tan minoritario como es el teatro infantil. Como este repaso analítico, el fondo acaba en 1939. En ese año acabaron también muchos proyectos e impulsos educativos, culturales y sociales que finalizaron con el estallido de nuestra Guerra Civil. Estas obras nos dan una imagen bastante fiel de la evolución de un teatro para niños que, como la propia Literatura Infantil, ha experimentado un cambio considerable.

Palabras clave: Teatro infantil, Biblioteca Pedro Cerrillo, fondo antiguo, teatro moralizante y escolar, renovación teatral infantil.

\section{[en] Step right up and read: the origin of the Spanish Children's Theatre in the Pedro Cerrillo Library (University of Castilla-La Mancha)}

Abstract. The main purpose of this paper is to publizice the old Children's Theatre collection in the Pedro Cerrillo Library (University of Castilla-La Mancha). We also want to claim research on Children's Theater, a very minority genre. The revision of this texts ends in 1939. On that date many educational, cultural and social projects also ended because of the Spanish civil war. These plays will allow us to know the evolution of Spanish children's theater in that period.

Keywords: Children's Theatre, Pedro Cerrillo Library, old collection, moralizing and school theater, Children's Theatre renovation.

Cómo citar: Sánchez Ortiz, C.; Rodríguez Abad, E. (2020). Pasen y lean: los orígenes del teatro infantil español en la Biblioteca Pedro Cerrillo de la Universidad de Castilla-La Mancha, en Talía. Revista de estudios teatrales, 2 , 65-72.

\section{El fondo antiguo de la biblioteca Pedro Cerrillo}

El 27 de octubre del año 2000 iniciaba su andadura la que hoy conocemos como Biblioteca Pedro C. Cerrillo, ubicada en el Campus de Cuenca de la Universidad de Castilla-La Mancha, una de las bibliotecas especializadas en Literatura Infantil y Juvenil más importantes en el territorio español. Adscrita al Centro de Estudios para la Promoción de la Lectura y Literatura Infantil (CEPLI), creado por el mismo Cerrillo un año antes, la apertura de la biblioteca materializaba un trabajo iniciado unos años antes, en 1997, cuando la Universidad de Castilla-La
Mancha adquirió unos 8000 volúmenes de la biblioteca personal de Carmen Bravo-Villasante ${ }^{1}$.

Carmen [Sánchez y Sanz 2018] realizó sus primeros estudios en el Colegio Francés para después continuar el bachillerato en el Instituto-Escuela, uno de los más avanzados y prestigiosos de la época. Con su tesis sobre La mujer vestida de hombre en el teatro español del Siglo de Oro se doctoró en Filosofía y Letras en la Universidad Central de Madrid. Su ferviente pasión por la cultura alemana le llevó a especializarse posteriormente en filología germánica. Realizó excelentes traducciones de autores alemanes como Goethe, Heine, Heinrich von

\footnotetext{
* Universidad de Castilla-La Mancha

Email: Cesar.Sortiz@uclm.es

** Universidad de La Laguna

Email: Erabad13@gmail.com

1 Carmen Bravo-Villasante (1918-1994) nació en Madrid, en el seno de una familia que le transmitió su pasión por el arte y la literatura [Sánchez y Sanz 2018: 17-21]. Su padre era óptico y permanecía muy en contacto con el ambiente cultural y humanístico de la época; su madre, un ama de casa adscrita al club femenino Lyceum. Este ambiente en el que se desarrolló su infancia sería el caldo de cultivo del que emergió la prestigiosa filóloga, folclorista y traductora, pionera en el estudio de la literatura infantil, que hoy conocemos. 
Kleist, Hölderlin y E.T.A Hoffman. En 1975 obtuvo el Premio Fray Luis de León por la traducción de Los elixires del diablo de este último autor.

Durante toda su vida se relacionó incansablemente con la cultura española, europea y americana: dictó conferencias por numerosos países, escribió artículos para la prensa, redactó prólogos, tradujo cuentos y publicó libros. También escribió interesantes biografías sobre Juan Valera, Pérez Galdós y Emilia Pardo Bazán, entre otros, y estudió minuciosamente la correspondencia entre estos y otros autores. Se interesó por la Historia de la Literatura Infantil y Juvenil, llegando a ser pionera y referente en el área, así como una reconocida bibliófila infantil hasta su fallecimiento, en 1994.

Hoy los anaqueles de esta biblioteca formada a partir de su colección personal ofrecen a estudiosos e investigadores más de 22.500 ejemplares catalogados, de los que unos 2300 componen el llamado Fondo Antiguo (libros infantiles anteriores a 1939). Paloma Alfaro [2000: 23], directora por aquel entonces de la Biblioteca Universitaria del campus conquense, data en 977 los asientos bibliográficos de ese fondo antiguo especializado en Literatura Infantil que se compraron a los familiares de esta estudiosa y pionera en la investigación en Literatura Infantil y Juvenil. Este fondo antiguo comprende títulos editados desde el año 1729, entre los que destacan ejemplares tan interesantes como Cuentos de hadas de Madame D'Aulnoy, obras de Madame Leprince de Beaumont, Fábulas de Tomás de Iriarte y de Florián, una de las primeras ediciones en alemán de la obra Der Struwwelpeter de Heinrich Hoffmann, innumerables ediciones escolares del Quijote, colecciones tan conocidas como la Biblioteca Perla o tan populares como los famosos Cuentos en colores de $\mathrm{Ca}$ lleja, o las primeras obras escritas para niños en nuestro país por Antoniorrobles o Bartolozzi. Junto a ellas, diversas y valiosas colecciones de revistas infantiles como $E l$ Camarada: semanario infantil ilustrado (1887-1891), la Gaceta de los Niños (1798-1800), Pinocho (1925-1927) o TBO (1917-1929). Y, entre todas, aunque en un número bastante insignificante respecto a los textos narrativos y poéticos, un puñado de obras teatrales para niños que, a menudo, pasan inadvertidas para estudiosos e investigadores y que son buena muestra de los orígenes del teatro infantil en España.

\section{La evolución del teatro infantil a finales del siglo XIX y principios del XX}

Si desde sus orígenes, la Literatura Infantil "se ha resentido en exceso de una necesidad 'oficial' de comunicar determinadas enseñanzas, ejemplos, valores, moralidades o doctrinas" [Cerrillo y Sánchez 2006: 9], lo mismo podemos afirmar de aquel teatro de finales del siglo XIX $\mathrm{y}$, en España, aunque con excepciones, de principios y mediados del siglo XX. Como a la LIJ, también a aquel teatro se le exigía [ibidem: 9] "no solo lo capacidad para instruir o adoctrinar, sino que, en sí mismo, fuera una parte esencial de la educación de los niños", olvidándose de otros valores como los literarios y, en nuestro caso, los artísticos, creativos y dramáticos.
En su Historia Crítica del Teatro Infantil, Juan Cervera [1982: 68] sitúa el origen del teatro infantil -tal como lo entendemos hoy [Muñoz Cáliz 2006: 13]- en la evolución de un teatro religioso y hagiográfico hacia uno de carácter más didáctico-moral, ya en el siglo XIX. Un teatro pensado en niños, representado por ellos y para ellos, que suponía la evolución del teatro universitario, saliendo de esas aulas para llegar a las escolares, una tarea llevada a cabo en un primer momento por los jesuitas en sus colegios. Y tras este periodo de transición, marca una segunda parte del teatro, que ocuparía los últimos años del siglo XIX y hasta el tardofranquismo, un teatro de la mano de la burguesía, que sigue buscando enseñar, pero al que se la añade, según avanza el tiempo, un componente también de diversión. A este segundo periodo pertenecerían la mayoría de las obras que nos ocupan, estas que llegaron a la biblioteca Pedro Cerrillo entre los fondos de Bravo Villasante, y que se publicaron en España entre 1905 y 1937.

\subsection{Pedro Jesús Solás}

Un claro ejemplo de ese teatro empapado de los valores de la moral burguesa es el texto dramático infantil más antiguo escrito en España, de entre los conservados en estos fondos documentales. Se trata de Al pie del faro: comedia infantil en un acto y en verso, escrita por Pedro Jesús Solás y publicada en la Editorial Bastinos (Barcelona) en 1905 dentro de su colección "Galería Dramática Nacional", y que años más tarde, ya en la década de los cuarenta, se reeditaría en la Galería Dramática Salesiana, añadiendo a su clasificación el matiz de "comedia moral". Una obra "para niños solos", dentro de la categoría de "un acto", escrita en octosílabos con estructura de romance que cambian de rima asonantada en cada cuadro. En ella, un niño obediente recibe la recompensa a su bondad en forma de reencuentro con un padre que parecía fallecido y dos nuevos amigos que, en su aparente pillaje y desobediencia, intentaron abusar de su bondad y acabaron cambiando su comportamiento y ganando una amistad. Cuatrocientos versos más morales que cómicos, que finalizan con la clásica apelación al público asistente:

$$
\begin{array}{cl}
\text { Ramón. } & \multicolumn{1}{c}{\text { Pero, }} \\
\text { antes de irnos, es preciso } \\
\text { que al auditorio roguemos. } \\
\text { Colás. } & \begin{array}{l}
\text { (Al público.) } \\
\text { Un aplauso para todos } \\
\text { si has quedado satisfecho. }
\end{array}
\end{array}
$$

Unos años después, Solás también participaría en la colección Teatro de Salón, de Manuel Ossorio Bernard, otro de aquellos primeros intentos de crear un teatro infantil en el que participarán escritores consagrados, y con la que intentó "cubrir las necesidades de la escena infantil y de los centros educativos interesados en esta tarea" [Cervera 1982: 94], con obras moralizadoras, costumbristas y típicas de celebraciones escolares como las propias del tiempo de Navidad. 


\subsection{Eduardo Sainz Noguera}

En esa misma línea encontramos La hechicera: cuento fantástico en un acto y tres cuadros, en prosa y verso, escrito por Eduardo Sainz Noguera y editado en Barcelona, en 1914, por los Sucesores de Blas Camí. Una obra breve, tan solo 31 páginas, de las que 12 corresponden a una partitura para interpretar parte del texto en formato canción, en la que Sainz Noguera, al igual que hicieran contemporáneos suyos como Pi i Arsuaga, Marinel $\cdot$ lo o Benavente, crea un teatro que hunde sus raíces en la cuentística tradicional, a mitad de camino entre la diversión y la enseñanza, predominando algo más esta última. Una línea teatral en la que el autor se desenvolvió bastante bien y que le permitió dirigir la colección Galería Dramática Nacional de la editorial Bastinos, que junto a Calleja y su colección Teatro de la Infancia, y el Teatro Escolar de Marinel·lo, fueron referentes de la producción editorial de teatro infantil en esas décadas. Además, muchas de las obras de Noguera acabarían publicándose posteriormente en la conocida Galería Dramática Salesiana. La obra que nos ocupa, junto a algún otro título del mismo autor, formó parte de la colección Galería Dramática Moral, dentro del grupo de teatro publicado "solo para niñas". En La hechicera podemos comprobar las características que, sobre el propio autor, fijase Cervera:

Eduardo Sainz Noguera es hombre entregado a esta labor de componer teatro para los niños. Un teatro que no escapa a las características de la época con su didactismo y moraleja, y en el que los tonos grises predominan sobre los brillantes, con versificación poco inspirada y a veces con sintaxis que deja transparentar la influencia del ambiente catalán en que trabaja [Cervera 1982: 103].

\subsection{José Ortiz de Pinedo}

Al autor de la tercera de las obras que nos ocupan, uno de esos ejemplares de difícil localización en bibliotecas $^{2}$, José Ortiz de Pinedo, lo encontramos ya mencionado en la clásica Historia de la Lengua y Literatura Castellana que entre 1915 y 1922 y en 14 tomos escribió y publicó Cejador en Madrid en la Tipografía de la Revista de Archivos, Bibliotecas y Museos. En ella nos dice Ortiz de Pinedo que es un escritor "natural, castizo y ameno, siempre agradable, y que retrata la realidad bien condesada" [tomo 13: 118]. Este periodista y escritor jienense destacó, sobre todo, en la narrativa popular por entregas semanales publicadas en prensa, aunque escribió también poesía, tradujo a Verlaine al castellano y firmó varias obras infantiles, entre ellas este Nuevo teatro infantil. Comedias, juguetes cómicos, diálogos, monólogos, farsas, fantasías, editado en Burgos, por los hijos de Santiago Rodríguez, en torno a 1925. Como el título anterior, ese teatro para niños ofrecía los textos de siempre a la vez que permitía avistar ese nuevo modelo de teatro de diversión, fantasía y humor. Así, podemos ver entre sus 166 páginas diálogos tan severos, como este:

María Isabel. Gravemente. Eso dicen las monjas, que soy lista.

Abuela. Y eso digo yo. Pero también digo -y supongo que las monjas dirán lo mismoque tanto como lista, eres desaplicada.

María Isabel. Muy seria. También lo dicen.

Abuela. ¿También, eh? ¡Naturalmente! Lo dice todo el que te vea, menos la pachorrona de tu madre, que todo te lo disculpa y todo te lo pasa, muy a disgusto mío.

Hay un silencio. La quietud de María Isabel parece prolongarse demasiado, y se advierte en ella algo así como un aleteo, como el ahuecar de plumas de un pájaro que va a echar a volar.

Abuela. Ya, ya estás pensando en escapar, en levantar el vuelo. Pues no, señora. Hoy tienes que escucharme, no faltaba más. Hoy me escuchas.

El pájaro, resignadamente, plega las alas, que ya se abrian en abanico. [Ortiz de Pinedo 1925: 54]

Junto a este texto, en el que se aprecia una cuidada calidad literaria, a pesar de lo breve del fragmento, pero que sigue la línea educativo-moralista de los títulos anteriores, sí encontramos ya algún indicio de ese nuevo teatro que anuncia el título. Sirva este ejemplo con la que abre la obra, una comedia de marionetas titulada Muñecos de barro:

El que vuelve Respetable público. Voy a tener los muñecos: el honor de presentar a vuestros infantiles ojos, el juguete cómico trágico titulado La cuestión es pasar el rato. Escrito para vuestro entretenimiento y el de vuestras chachas y nodrizas por un precoz autor dramático de biberón y chichonera; y espero de tan llorona y distinguida concurrencia, que escuche el pasatiempo con la mayor atención posible, sin rabietas, lloriqueos ni otros excesos que la honestidad me veda decir, y que al final le otorguéis vuestros aplausos con toda la fuerza de vuestros sonajeros. ¡Quietecitos, que va a empezar! [Ortiz de Pinedo 1925: 6].

\subsection{Micaela de Peñaranda}

Micaela de Peñaranda (1872-1949) es la primera mujer escritora de teatro infantil que encontramos en el fondo 
antiguo de esta biblioteca. Fundadora, junto a varias de sus hermanas, de una orden religiosa dedicada a la enseñanza y las obras de caridad, Micaela escribió desde su celda novela, poesía y piezas teatrales, todas íntimamente relacionadas, como se puede suponer, con la moral católica. Molina Angulo y Selfa [2019: 157] citan a Micaela, junto a otras autoras teatrales del periodo de entreguerras (1918-1936) -como Pilar Contreras, Carolina de Soto o Matilde Ribot- como las continuadoras del "teatro decimonónico, un teatro escrito casi siempre en verso, con muchos elementos retóricos que dificultaba su comprensión por parte del niño y un nivel lingüístico del texto totalmente inadecuado. Pero, que "tuvo muy buena acogida en los círculos católicos y en colegios religiosos. Su función era doble: por un lado, el adoctrinamiento moral y religioso de la prole frente a modelos de conducta que eran censurables; por otro, era un tipo de texto destinado a la representación y que ofrecía una ocasión de esparcimiento" [Molina Angulo y Selfa 2019: 157].

La obra en cuestión, Teatro infantil: piezas en prosa y verso, editada por la Librería Religiosa de Barcelona en 1926, tiene un total de 133 páginas que acogen piezas muy breves, tanto en prosa como en verso, destinadas a la correcta formación moral de las protagonistas y, por ende, del público asistente. Sobre ellas y su sencillez, que ralla a veces con la simplicidad, dice Itziar Pascual que entre sus características principales cabe destacar que:

se resuelven de forma explícita, y con frecuencia precipitada, con un claro subrayado ideológico en su conclusión, con frecuencia rompiendo la cuarta pared y dirigiéndose explícitamente al público; los personajes se fundamentan en tipologías generales, dando gran valor al estatuto social y a la edad (adultos y ancianos son aquellos que vienen a proponer un modelo de conducta) [Pascual 2008: 25].

Así como otras muchas características en la misma línea, como la ausencia de acción dramática o la nula progresión psicológica de los personajes, que pasan de una conducta inadecuada a otra más modélica simplemente escuchando a sus mayores y pidiendo perdón.

\subsection{Manuel Medina Olmos}

No abandonamos tampoco la relación de la Iglesia Católica con el teatro infantil en el siguiente libro de este fondo antiguo. Escrito por el sacerdote y beato español Manuel Medina Olmos con el título de Teatro infantil. Cuaderno 4 (para niñas), nos pone en antecedentes de la existencia de, al menos, otros tres textos para niñas, que no se encuentran en estos anaqueles. La contracubierta nos indicará que hasta ese momento eran 8 los escritos para niñas y tres los escritos para niños. Editado en 1935 en Granada, en la Imprenta-Escuela del Ave María, sus 63 páginas recogen tres obras para niñas: La hija del rabino (drama en dos actos); La gitanilla de Belén (pasillo de Navidad en dos cuadros) y El arte de vestir bien (apropósito cómico).
El final de la última de las tres obras, el apropósito, es una muestra más de la continuidad de este teatro que, ya bien avanzados los años 30 , seguía unido a esta intención formativa moral, mientras ya se estaba representando el que realmente podríamos llamar nuevo teatro. Obsérvese la utilización de un lenguaje vulgar, iletrado, para representar a las clases sociales bajas, sin formación, y víctimas de las inmoralidades:

Ruper. Entonces, zeñorita, ¿qué me dice ozté de las mujeres que llevan los vestíos cortos, y de las que llevan el cuerpo desnúo, luciendo lo que debieran de tapar?

Rosario. Que son dos formas de empezar a perder la vergüenza y de iniciar y estimular al pecado.

Ruper. (Cae de rodillas delante de Rosario) Déjeme ozté, zeñora, que caiga de roíllas delante de zu prezona, poque quien azí habla merece una corona de reina.

Rosario. No la rechazo, pero no la quiero para mí, sino que la he de guardar para ponerla en las sienes de aquellas niñas que hayan aprendido esta lección y sepan aprovecharla. Así lograrán poseer El arte de vestir bien. (Telón) [Medina Olmos 1935: 63].

\subsection{Fernando José de Larra y Larra}

Fernando José de Larra y Larra, tataranieto del célebre escritor romántico, también publicó teatro infantil, un teatro "escolar" más cercano al que conocemos hoy por ese término, algo alejado de tanta moralidad, pero aún muy empapado de un pensamiento conservador. De hecho, al igual que veíamos en el caso anterior respecto al uso del lenguaje como identidad cultural y de clase, en alguna de estas obras, como La escuela nueva, el autor señala sobre ese texto que es "muy adecuado para la inauguración de un grupo escolar y que puede decirlo un chico de cualquier edad. Solo se le pide que exagere un poco el acento peculiar del pueblo donde haya nacido" [Larra y Larra 1928]. En sus doce tomos de La farándula, niña: teatro infantil, editado en un solo volumen en 1928 en Madrid por Tipografía Yagües, y en tomos independientes un año más tarde, contó en ambas publicaciones con sendos prólogos del filólogo César Juarros y de los hermanos Álvarez Quintero respectivamente. Aunque supuso un fenómeno editorial en su tiempo -llegó a venderse incluso antes de ser estrenado sobre las tablas, algo poco frecuente-, investigadores como Cervera no comparten tanto entusiasmo atribuyendo que tal vez "la condición familiar y la posición política y social del autor hayan hecho que este libro haya sido encomiado teniendo en cuenta más su apariencia literaria que su valor dramático real y su significación en el desarrollo del teatro infantil" [Cervera 1982: 140].

En cualquier caso, estas son las doce obras y sus consiguientes breves explicaciones por parte del autor: $E l$ dinero de las niñas. Apropósito en defensa del ahorro infantil; La fiesta del árbol. Discurso infantil con apos- 
tillas cómicas; Sueño de Carnaval. Bailable infantil de gran espectáculo; La nueva escuela. Monólogo para la inauguración de un edificio escolar; Las figuras del Belén. Auto infantil de Navidad; El retrato. Monólogo para público infantil; El campo y la ciudad. Diálogo trascendental. Premio en el concurso de la revista Blanco y Negro; La libertad de los muñecos. Farsa para niños ricos; La fiesta de la flor. Diálogos de circunstancias; Los charlatanes. Escena callejera tomada al natural; El soldadito. Monólogo patriótico; La fuente de los amores. Comedia ingenua para capullos de mujer.

\section{El nuevo teatro para niños}

Acabamos este repaso en los años 30, la Edad de Plata de la Literatura Infantil y Juvenil española, de la que lógicamente también participó el teatro para niños. García Padrino nos habla, por ejemplo, de que en los primeros años 30 se tuvo noticia de un espectáculo teatral organizado con escolares de la ciudad de Madrid y en el que se representó, entre otras obras, La Pájara Pinta de Rafael Alberti: "Se trataría de una actividad dramática volcada a un texto de la tradición folclórica infantil y que tendría evidente relación con la innegable renovación pedagógica impulsada por la II República Española" [García Padrino 1997: 16]. Esta renovación teatral tuvo, también, nombre de mujer: Elena Fortún, Magda Donato o Concha Méndez son tres de estas geniales dramaturgas que, con la Guerra Civil, tuvieron que exilarse. De hecho, Elena Fortún, junto a Magda Donato, "formaron parte como vocales de la Comisión de Teatro de los Niños, creada por una Orden del Ministerio de Instrucción Pública, fechada el 6 de enero de 1938, publicada en la Gaceta de la República el 18 de enero de 1938 y presidida por Benavente [Aznar 1993: 215].

El teatro de estas mujeres supuso la transición hacia un nuevo tipo de teatro en el que los temas y el tratamiento que hace de estos permiten hablar de la concepción abierta y novedosa de este género:

No se trata de un teatro completamente innovador respecto al que se iba escribiendo y representando en la época, pero sí que observamos elementos novedosos que dan un nuevo aire a la escena española femenina de los años 20 y 30 del siglo pasado. Entre estos elementos destacan el uso de un lenguaje ágil, vivo, muy próximo al lenguaje infantil y desligado de la dicción del verso; la inclusión de elementos populares como dichos y canciones populares; las frecuentes acotaciones que nos dan una idea exacta de cómo es toda la escenografía que rodea la obra teatral; la progresiva desmitificación de los personajes de cuentos infantiles pero sin llegar a despojarlos de su halo fantástico; y la alusión frecuente al recurso del humor [Molina Angulo y Selfa 2019: 158-159].

\subsection{Magda Donato y Salvador Bartolozzi}

Enmarcada, ahora sí, en este nuevo teatro infantil, la última de las obras de las que nos ocuparemos es la firma- da por Magda Donato y Salvador Bartolozzi: Pipo, Pipa y el lobo Tragalotodo, una comedia infantil en dos actos divididos en doce cuadros, editada por los Sucesores de Rivadeneira poco antes de la huida al exilio de esta prolífica pareja. La vida de sus dos protagonistas viene de tiempo atrás, concretamente de una serie de libritos impresos en un papel muy humilde, con 16 páginas cada uno, titulados "Las maravillosas aventuras de Pipo y Pipa". Aprovechando la estructura dramática que los autores confirieron a estos cuadernillos (lenguaje literario, acotaciones, estructura dialogada, descripción de escenarios...) muchas de estas aventuras fueron puestas en escena por actores profesionales, de tal modo que de los textos para esas representaciones se publicó "en la colección La Farsa el volumen titulado Pipo, Pipa y el lobo Tragalotodo [...] obra estrenada en el Teatro María Isabel, de Madrid, el 7 de noviembre de 1935" [García Padrino 2001: 58-59]. Junto a nombres como Lorca, Alberti o Casona, que lograron unir las obras teatrales para niños con la poesía y el humor, así como la renovación plástica de los mismos, tanto en las representaciones como en su lenguaje literario, Donato, junto a Elena Fortún o Bartolozzi, fueron responsables durante este periodo del teatro publicado para ser representado por niños y editado en la prensa u otros soportes efímeros y asequibles [Lozano Palacios 2012: 31].

Afirma Urzáiz Tortajada que además de los grandes nombres del teatro español de la Edad de Oro "hay muchos otros dramaturgos menores con obras censuradas que sin duda podrían ser objeto de estudio" [Urzáiz 2019: 7]. Es el caso de Bartolozzi y Donato, autores de esta última obra mencionada. Triunfadores en México, donde la pareja alcanzó el éxito económico y profesional, continuando las publicaciones de sus principales más conocidos -Pinocho, Chapete, Pipo, Pipa, etc.- y llegando incluso a dirigir y organizar el Teatro Infantil del prestigioso Palacio de Bellas Artes, en España sus nombres fueron silenciados y eliminados de todas sus obras, que siguieron vendiéndose y representándose sin hacer referencia a la propiedad intelectual de sus autores, que fue eliminada y tachada de todas las páginas donde constara: portada, cubierta, página de créditos, pie de ilustraciones, programas de mano, catálogos editoriales... [Cerrillo y Sotomayor 2016: 147-153].

\section{Conclusiones}

Acaba así este repaso que pretendía, como principal objetivo, dar a conocer los fondos antiguos de teatro infantil de la Biblioteca Pedro Cerrillo de la Universidad de Castilla-La Mancha, además de reivindicar los estudios e investigaciones en un género tan minoritario como es el teatro infantil. El fondo acaba en 1939 y nuestro repaso por este teatro acaba también aquí, como acabaron tantos proyectos e impulsos educativos, culturales y sociales que se dieron al traste con el estallido de nuestra Guerra Civil. Estas obras nos dan una imagen bastante fiel de la evolución de un teatro para niños que, como la propia Literatura Infantil, ha experimentado un cambio 
considerable, generalmente de la mano de grandes autores, para llegar hasta lo que hoy entendemos, o deberíamos entender, como teatro para niños y jóvenes. Un teatro que, lógicamente, irá en estas edades de la mano de la didáctica, pero que no puede dejar de lado vertientes igual o más importantes.

El teatro es un juego artístico en el que se conjugan capacidades y fantasía. La concentración, la memoria, el concepto de trabajo en colectividad, como decía Federico García Lorca. El teatro es un juego que parte de las emociones y nos hace viajar a los conflictos del ser humano. No entendemos en estos momentos la comprensión de cualquiera de las artes sin sumergirnos en el sentimiento interior que generan la palabra, el gesto, el color, el sonido...

No podemos cuidar solo el intelecto o el cuerpo. No debemos basarnos únicamente en las reacciones lógicas o físicas. Sensaciones, emociones, sentimientos son la materia prima de la composición artística y deben ser la base de su comprensión en las primeras etapas de la enseñanza. Hay que desarrollar la intuición y la capacidad generadora de imágenes, ideas, conceptos.

Así debemos tener en cuenta que el teatro es juego. Es una manera de traspasar la realidad y entrar en el universo de lo simbólico. Desde pequeños somos capaces de adquirir roles diferentes, de inventar juegos que desarrollen nuestra capacidad de interpretación. Como apunta el escritor Paco Abril [2003: 26]: "La imaginación no es sólo la loca de la casa, como tantas veces se ha dicho, sino que es una capacidad sin la cual la humanidad no habría podido salir del estado animal."

El teatro es además expresión. Todo el mundo interior se puede ver reflejado en la escena, mediante la conjunción de signos que entretejen el conflicto. Es un cuadro en movimiento lleno de matices y de sentimientos. Es la representación del lenguaje escrito, que se convierte en una voz con esquinas. Mediante la expresión con el cuerpo, creación de un lenguaje con nuestras manos, nuestros pies, ojos, boca... Todo el cuerpo habla con sus propias normas y con el código creado a partir de la conjunción de signos. Es lenguaje también de la música, de los colores y las formas, del decorado y del vestuario, de las luces que crean sensaciones e imágenes en el aire.

Pero debemos pensar también que el teatro o la dramatización no son solo una herramienta eficaz en los procesos educativos. El arte escénico conlleva una manera de acceder al lenguaje de la literatura. El teatro nos conduce al mundo de la cultura. Las tradiciones de cualquier país, región o comunidad se pueden encontrar en las manifestaciones teatrales que transmiten a la largo de los siglos valores, costumbres y ritos que nos acercan a conocer mejor al ser humano. García Lorca apunta en una charla sobre teatro que:

El teatro es uno de los más expresivos y útiles instrumentos para la educación de un país y el barómetro que marca su grandeza o su descenso. Un teatro sensible y bien orientado en todas sus ramas, desde la tragedia al vodevil, puede cambiar en pocos años la sensibilidad de un pueblo; un teatro destrozado, donde las pezuñas sustituyen a las alas, puede acha- bacanar y adormecer a una nación entera. El teatro es una escuela de llanto y de risa y una tribuna libre donde los hombres pueden poner en evidencia morales viejas o equívocas y explicar con ejemplos vivos normas eternas del corazón y del sentimiento del hombre [1996: 225].

El texto dramático que se ofrece al mundo infantil o juvenil debe tener un compromiso con la calidad y con la realidad infantil. No olvidemos otra de las características que hacen que el teatro sea una de las armas o herramientas imprescindibles en el desarrollo de las personas: El teatro es comunicación. Sin un público no podemos hacer la función teatral. Se crea una necesidad de nutrirse mutuamente, como argumenta Jorge Dubatti [2007: 160]: "El artista sale a la búsqueda del espectador porque lo necesita; el espectador sale a la búsqueda del artista también por necesidad". Por ello es necesario educar y crear el concepto de espectador que sepa descodificar el signo dramático. Formar estudiantes que sepan ser espectadores, que conozcan los mecanismos y las características de la escritura teatral y de la representación escénica. Es mucho más necesario en lugares en los que apenas hay tradición teatral estable y en los que no se ha desarrollado una programación que llegue a todos los públicos y en los que el teatro infantil o dedicado a los niños es una incipiente y tímida propuesta, sin la seguridad y la estabilidad que debería tener un teatro permanente para niños, como sería lógico en una sociedad desarrollada.

Comunicación pues complicada, ya que son muchos signos imbricados que hay que comprender. Si se trabajase con la seriedad y con la dedicación debida sería uno de los elementos que harían comprender a los alumnos muchos procesos semióticos.

También es acercamiento a la cultura y la literatura. El trabajo del texto, para poderlo interpretar ha de ser intenso y de total comprensión. Además, hay que descubrir las acciones y emociones que encierra cada palabra. Así el niño que interpreta papeles en obras de probada calidad literaria se está acercando a un conocimiento y consumo de la literatura desde los conceptos que antes hemos explicado.

Podemos concluir constatando que el teatro es también liberación, tanto individual como colectiva. En este arte se produce la magia de la transformación, tanto del actor como del público. La catarsis entre escenario y público sucede a pesar de que todos sepan que lo que allí sucede es una ficción. Es una realidad inventada.

No podemos olvidar que el teatro es una ceremonia, es rito, desde tiempos inmemoriales y que como tal debe ser tratado. No es normal ir a cualquier rito sin prepararse, sin crear la sensación de que estamos acudiendo a un hecho mágico y poco habitual.

No creemos por tanto conveniente obligar a ver una pieza teatral sin crear la necesidad de verla, sin desarrollar todos los aspectos que conlleva la dramatización.

Así el teatro se convierte en un diálogo entre espectador y emisor (o emisores). El público infantil busca en la escena una respuesta a sus conflictos con el mundo que no entiende. Su viaje iniciativo para reconstruirse como 
persona lo hace en el universo artístico que le proporciona la escena.

Comprender el arte se logra si nos enseñan a mirar. Es la mirada nueva, distinta, la que hace que comprendamos símbolos, imágenes y sonidos que van más allá del uso cotidiano del lenguaje, de los objetos, de los gestos y de los colores.

Las personas que supieron llegar al bosque escondido ya no quisieron regresar. Habían aprendido el valor de las palabras, los colores de las cosas, los milagros que pueden ver los ojos y los oídos cuando se ha llegado al árbol del lenguaje oscuro. Transitar por el arte es perderse en ese bosque y no querer salir de él.

Desde los inicios a la renovación que supone el siglo $\mathrm{XX}$ el teatro ha tratado de resolver conflictos, como dice María Jesús Ruiz en su artículo "El romancero a escena: el teatro infantil en la Edad de Plata": "los autores del teatro infantil de la Edad de Plata quisieron ofrecer a sus niños una esperanza de futuro construida con su propia memoria cultural" [2019: 35].

Desde el teatro independiente de las parroquias y las escuelas, y para el cual escribiesen los mejores dramaturgos de la época al proyecto entusiasta del Premio Nobel Jacinto Benavente a favor de un teatro nacional para la infancia, el teatro de los niños ha estado presente en el desarrollo de la actividad cultural infantil en el siglo XX. En 1909 se estrenaba El príncipe que todo lo aprendió en los libros del propio Benavente, a la que siguieron otras piezas infantiles suyas como La cenicienta, $\mathrm{Va}$ de cuento, El nietecito o Ganarse la vida. Valle Inclán - La farsa infantil de la cabeza del dragón (1910)- o Eduardo Marquina-La muñeca irrompible (también en 1910)- pusieron su creatividad al servicio de la literatura escrita para niños, aportando piezas fundamentales en el desarrollo teatro infantil. Habría que destacar también la aportación de los hermanos Álvarez Quintero, que estrenan en 1909 La muela del rey Farfán, obra musical que no tuvo éxito en su estreno. La idea de Jacinto Benavente no fue lo bien recibida que se merecía en la sociedad de la época. Tampoco las instituciones apoyaron como merecía el proyecto, por ello su vida fue efímera.

Habría que destacar el trabajo teatral pensado para la infancia que se desarrolló en la vanguardia española. En esos años se buscó en este género un universo artístico enraizado en lo popular y no contaminado por los manidos cánones del teatro burgués, acomodado a formas ya desfasadas. Así encontramos propuestas de Manuel de Falla, Federico García Lorca, Rafael Alberti, Salvador Bartolossi, Rivas Cheriff, Jacinto Grau... También destacaríamos la obra del titiritero, Francisco Porras, que mantuvo su teatrillo en contra de modas, de devaneos políticos y del poco apoyo oficial.

En la primera mitad del siglo XX, después de la irrupción de estos autores surgen figuras como Elena
Fortún que en su Teatro para niños (1936), inicia una renovada visión de la que puede ser un teatro escrito para un público infantil. Los criterios de la autora se alejan del didactismo y aboga por aportaciones puramente artísticas, cercanas al mundo de la infancia con puntos de vista y conflictos cercanos al mundo de los niños.

Con la caída de la dictadura y la llegada de la democracia, aires nuevos inflaman nuestras letras y el teatro para niños se renueva. El cambio histórico y social introduce nuevos patrones de comportamiento y frente a los personajes modelo de virtudes del teatro decimonónico se empiezan a plasmar las contradicciones entre el universo infantil y el sistema de obligaciones que los adultos les imponemos. En los textos nuevos se empieza a ver cierta complicidad con el universo infantil, se critica el sistema de vida rígido, se ridiculiza la autoridad inflexible y se plantean textos que hablan de los valores que la nueva sociedad quiere rescatar. Los comportamientos sociales cambian lo mismo que los roles familiares y educativos. Los conflictos que refleja el nuevo teatro para niños están relacionados con la tolerancia, la no discriminación y el respeto a la diferencia, junto a variados mensajes reivindicativos asociados con la defensa del medio ambiente, los derechos humanos, la igualdad de sexos o la paz. Aunque han cambiado las ideas y ya no se adoctrina desde puntos de vista conservadores se sigue inutilizando el teatro, en muchas ocasiones, con el objetivo de transmitir ideas y con la meta de propiciar un disfrute por el arte a la vez que ven reflejados conflictos eternos del ser humano.

Un dato significativo en esta nueva etapa histórica en la que hay gran diversidad en la calidad es que se abre mucho el abanico de los temas y en algo se modifica su tratamiento, especialmente en lo que se refiere al papel de la imaginación, a la reducción del paternalismo y a la búsqueda imprescindible de la diversión del público infantil.

La influencia de las vanguardias, el cine y la publicidad, junto a la mezcla y aparición de nuevos géneros como la ciencia-ficción o la comedia musical, va a tener una respuesta en el teatro a través de nuevas formas expresivas y de la ruptura de ciertas convenciones escénicas en algunas obras innovadoras que coexisten junto a un teatro conservador que mantiene las formas tradicionales.

Pero la esencia de la representación siempre será esa comunión entre espectador y emisor. Ni el teatro ni un libro termina cuando cae el telón. "En este momento es cuando comienza el verdadero y suculento disfrute" [Rodríguez Abad 2008: 116]. Es en la charla, en la crítica, en el debate posterior donde el espectador o el lector hacen su construcción personal y única del espectáculo o del libro.

\section{Referencias bibliográficas}


Alfaro Torres, Paloma (2000): "Introducción metodológica al catálogo descriptivo", en C. J. Martínez y S. Sánchez (coords.): Colección Carmen Bravo-Villasante, catálogo bibliográfico (fondo antiguo), Cuenca, Ediciones de la Universidad de Casti1la-La Mancha: 23-24.

Aznar Soler, Manuel (1993): Max Aub y la vanguardia teatral (Escritos sobre teatro, 1928- 1938), Valencia, Universitat de Valencia.

Cerrillo, Pedro C. y César Sánchez, (2006): “Literatura con mayúsculas”, Ocnos. Revista de estudios sobre lectura, 2: 7-21.

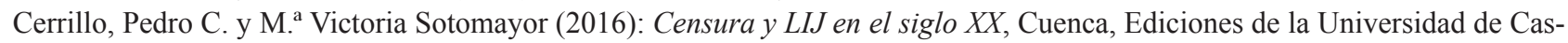
tilla-La Mancha.

Cervera, Juan (1982): Historia critica del teatro infantil español, Madrid, Editora Nacional.

Dubatti, Jorge (2007): Filosofía del teatro I, Buenos Aires, Ariel.

García Lorca, Federico (1996): Obras completas, Barcelona, Círculo de Lectores.

García Padrino, Jaime (1997): "Promoción y difusión del teatro infantil en la escuela”, en Pedro Cerrillo y Jaime García Padrino (coords.): Teatro infantil y dramatización escolar, Cuenca, Ediciones de la Universidad de Castilla-La Mancha: 11-36.

- (2001): Así pasaron muchos años... (En torno a la Literatura Infantil Española), Cuenca, Ediciones de la Universidad de Castilla-La Mancha.

Larra y Larra, Fernando José de (1928): La farándula, niña: teatro infantil, Madrid, Tipografía Yagües.

Lozano Palacios, M. ${ }^{a}$ Isabel (2012): Aproximación a la literatura dramática juvenil actual: definición, determinación del corpus y análisis. Tesis, Universidad de Alcalá de Henares.

Molina Angulo, Raquel y Moisés Selfa (2019): "El teatro femenino de preguerra en España: Elena Fortún y su Teatro para niños (1936)", Revista de Literatura, 161: 53-175, Recurso web https://doi.org/10.3989/revliteratura.2019.01.007, Fecha de consulta: $20-\mathrm{I}-20$.

Medina Olmos, Manuel (1935): Teatro infantil. Cuaderno 4 (para niñas), Granada, Imprenta-Escuela del Ave María.

Muñoz Cáliz, Berta (2006): Panorama de los libros teatrales para niños y jóvenes, Madrid, ASSITEJ-España.

Ortiz de Pinedo, José (1915-1922): Historia de la Lengua y Literatura Castellana, 14 tomos, Madrid, Cejador.

Pascual, Itziar (2008) (ed.): Teatro español para la infancia y la juventud (1800-1936), Madrid, Editorial Fundamentos.

Peñaranda, Micaela de (1926): Teatro infantil: piezas en prosa y verso, Barcelona, Librería Religiosa.

- (1925): Nuevo teatro infantil. Comedias, juguetes cómicos, diálogos, monólogos, farsas, fantasías, Burgos, Hijos de Santiago Rodríguez.

Rodríguez Abad, Ernesto (2008): Juegos teatrales para animar a leer, Madrid, Catarata.

Ruiz, María Jesús (2019): "El romancero a escena: teatro infantil de la Edad de Plata”, Mnemosyne, 23: 35.

Sainz Noguera, Eduardo (1914): La hechicera: cuento fantástico en un acto y tres cuadros, en prosa y verso, Barcelona, Sucesores de Blas Camí.

Sánchez, C. y A. Sanz (2018): “Carmen Bravo Villasante, retazos de una vida (1918-2018)”, Lazarillo, Revista de la Asociación Española de Amigos del Libro Infantil y Juvenil, año XXXV, 2a época, n. 39: 17-21.

Solás, Pedro Jesús (1905): Al pie del faro: comedia infantil en un acto y en verso, Barcelona, Bastinos.

Urzáiz Tortajada, Héctor (2019): "La censura del teatro clásico español”, Talía. Revista de estudios teatrales, 1: 1-8. 